\title{
Validation of a Computerized Decision Support System To Review Pharmacotherapy Treatment: Scheduling Guidelines
}

Clávison Martinelli Zapelini

University of Southern Santa Catarina (UNISUL)

Dayani Galato

Brasília University (UNB)

Graziela Modolon Alano

Pharmacy School at University of Southern Santa Catarina (UNISUL)

Karina Saviatto Carvalho Martins

Pharmacy School at University of Southern Santa Catarina (UNISUL)

\section{Silvana Cristina Trauthman}

Pharmacy School at University of Southern Santa Catarina (UNISUL)

Alessandra Sá Soares

University of Southern Santa Catarina (UNISUL)

Fabiana Schuelter Trevisol ( $\nabla$ fastrevisol@gmail.com )

Tubarão - Santa Catarina

Daisson José Trevisol

Clinical Research Center at Hospital Nossa Senhora da Conceição

\section{Research Article}

Keywords: Pharmaceutical Care, Clinical Pharmacy Information Systems, Drug Usage Review

Posted Date: September 2nd, 2021

DOI: https://doi.org/10.21203/rs.3.rs-797574/v1

License: (c) (i) This work is licensed under a Creative Commons Attribution 4.0 International License. Read Full License 


\section{Abstract \\ Background}

In the pharmacotherapy review process, the pharmacist needs to list various information about the patient and the set of medications he will use, information that is never available at the point of care.

\section{Methods}

The aim of the study was to validate an intelligent information system, which was developed to assist the scheduling activity in the pharmacotherapy review process. The system used the concept of Genetic Algorithms. To validate it, appointments of hypothetical cases (ten) were made by the system and by human specialists. These schedules were qualitatively evaluated by pharmaceutical specialists with clinical and research experience in the pharmacotherapy review process. The degree of agreement between the assessments of the appointments carried out by the pharmaceutical specialists and by the system were measured using the Kappa index with a 95\% confidence interval.

\section{Results}

In detecting errors, propositions, the system was able to identify $80 \%$ of errors, with human specialists identifying between $20 \%$ and $70 \%$ of errors. In relation to the general evaluation, the system obtained $87,3 \%$ of the compared evaluations, with the human specialist who came closest to this index obtained $75,5 \%$.

\section{Conclusion}

It can be concluded that with the methodology used, the investigation met the objectives and confirmed the initial hypothesis. There are indications that the system can help in the Pharmacotherapy review process, being able to find prescription errors as well as to establish times for the use of medications according to the patient's routine.

\section{Background}

According to the World Health Organization (WHO), more than half of all medicines marketed in the world are incorrectly prescribed or dispensed; as a result, more than $50 \%$ of patients don't use them or use them incorrectly ${ }^{1}$. In Brazil, several factors contribute to this reality, including polypharmacy, which still does not have a standardized term in the scientific literature regarding the use of the number of drugs, the indiscriminate use of antibiotics, self-medication, prescription without clinical guidelines and dispensing not in compliance with the RUM (Rational Use of Medicines) ${ }^{2}$. 
One of the actions to reduce drug-related problems is the practice of pharmacotherapy review, in which the pharmacist evaluates prescriptions in order to find potential inconsistencies and suggests a strategy for the medication to be used by the patient, whether they are drugs that gave rise to the service or medications that are already in use, readjusting the doses and times (schedule) so that the treatment is not incompatible or in duplicity.

The review of pharmacotherapy can be conceptualized as a service in which an the drugs used by the patient are reviewed in order to control the risks as well as to improve the results of the drug therapy, detecting, solving and preventing issues associated with the drug. This assessment must be structured and carried out with the patient, aiming at increasing adherence and minimizing potential errors ${ }^{3}$. Several studies have shown that the review of pharmacotherapy is beneficial to patients and fosters the rational use of medication ${ }^{3,4}$. However, the review of pharmacotherapy is quite difficult because the search for reliable technical information about the drugs is required. In addition the process is complex due its connection with the patients' profile and the pharmacotherapy adopted. Thus, time is needed to perform such review and, sometimes, the lack of quality information hampers this service performance ${ }^{5}$.

The use of information systems facilitates a rapid search for information; however, in order for the system to design a strategy for the drug use, it is not sufficient to have the information available; one must list all the variables and use intelligence mechanisms to reproduce the reasoning of the pharmaceutical expert. Therefore, technology and algorithms selection are factors that deserve to be highlighted. Among the several options is the area of Artificial Intelligence (Al), which is composed of algorithms that simulate human intelligence, making inferences and learning from new problems. One of the Al techniques is the Genetic Algorithms (GA), which are used in optimization problems, that is, problems that search for the best solution among all possible solutions ${ }^{6}$.

Intelligent systems, because they seek to get closer to human brain behavior in order to make the necessary inferences, are able to learn from specialists based on the representation of clinical reasoning through rules inserted in a database. Once trained, these systems are free of contextual factors that can induce errors, factors that are inherent only in human beings. As GA are used for classic optimization problems, it was assumed that, in terms of computer technology, it is an option to optimize the timing of medications to be used by a given patient, listing all the variables that can interfere in this process ${ }^{7}$.

The development of health information systems due to their interdisciplinary nature and the need for aggregation of different professional knowledge, requires a strict validation process so that all resources offered by the system be efficient and reliable ${ }^{8-10}$. Health validation research generally involves the concepts of data collection instruments, with a focus on content validation, construct validation and validation related to a criterion. The reliability of data collection instruments is also assessed ${ }^{11-13}$. Thus, to assist in the pharmacotherapy review process, this research aimed to validate an intelligent information system, which, in addition to making information available to pharmacists, could also propose the adjustment of schedules and doses, thus simulating the pharmaceutical expert's reasoning through the use of genetic algorithms. 


\section{Methods}

The validation process was divided into three methodological steps, guided by theoretical assumptions that refer to the validation and reliability of data collection instruments.

In the first stage, the necessary records for the system's operation were carried out; the system test was performed and ten hypothetical cases were created that were sequentially coded (from one to ten) simulating patients with different routines and different drugs to be used. Both the patient's name and his/her routine were not real; however, they were based on situations that simulated daily life and covered different situations that involve different knowledge and skills for an adequate review of pharmacotherapy and scheduling. The records and cases were prepared by three professional pharmacists together with a professional who worked as a nurse, and the tests were performed by a professional in the computer field. Each case had some inconsistency or specific analysis situation, according to Table 1. In this case it was the first verification made by the system. These inconsistencies were kept confidential at all stages of validation. 
Table 1

- Predicted situations for hypothetical cases.

\section{Analysis situation}

Medicine that should not be used concurrently

Prescription for patients who have an active daytime routine.

Prescription for patients who have an active night routine

Medicines that require a minimum interval between doses.

Prescription for a patient who has a health condition in which a drug is contraindicated.

Overdose prescription for a particular drug.

\section{Hypothetical cases}

"ACETYL-SALICYLIC ACID" and "WARFARIN" present in drugs "ASPIRIN $500 \mathrm{mg}$ " and "WARFARIN $2.5 \mathrm{mg}$ " in the same prescription

Patient who wakes up at 7am, work from $8 \mathrm{am}$ to $12 \mathrm{pm}$ and from $1 \mathrm{pm}$ to $6 \mathrm{pm}$. Sleeps at $10 \mathrm{pm}$.

Patient who works from $10 \mathrm{pm}$ to $6 \mathrm{am}$ and sleeps from 7:30am to 2:30pm.

Use of "DIGOXIN" and "MYLANTA PLUS ${ }^{\circ}$ " which have interaction between active principles "DIGOXIN" and "ALUMINUM HYDROXIDE" requiring an interval between doses.

Patient with severe liver disease (cirrhosis) with prescription of "ATORVASTATIN CALCIUM" which is contraindicated drug for this situation.

2-years-old child weighing $13 \mathrm{~kg}$ with a prescription of the "AZITROMYCIN" with a dose higher than the maximum dosage allowed for the child's weight.

Prescription of "OMEPRAZOLE" which is indicated to be used on an empty stomach.

6-years-old child who needs antibiotics every 8 hours.

Prescription for patients in which sleep disruption should be avoided.

Medicine with indication not to be used, but by clinical decision opted for the risk.

Medicines that need specific guidelines for use.
"CARBAMAZEPINE" for a pregnant woman with 12 weeks of gestation, to avoid epilepsy crises.

Use of "ALENDRONATE SODIUM" and "LEVOTHYROXINE".

In the second stage, the simulated cases were submitted to the pharmacotherapy for review and the schedule was established by five dedicated pharmacists. In parallel, those cases were also scheduled by the system, generating a total of six schedules for each case.

Pharmacists filled out a standardized table that contained the use schedule they recommended, the name of the drug, the dosage, as well as a space for them to enter notes next to each drug, if they thought necessary, such as instructions on the use, prescription reassessment recommendation, among others.

In addition to the information in the table, which was filled in for each drug, the form contained a space for justification regarding the schedule made, or not made for some reason. In this justification, the pharmacist could include information that he/she would deem relevant for the scheduling, such as 
prescription errors that should be revised, observations of inconsistency or suggestions for the adequacy of medications. For the last validation step, pharmacists were identified by a number (from one to five) and were called human specialists (terminology used in the computational area to differentiate the human specialist from the specialist system).

The cases were also submitted for scheduling to be carried out by the system; such system was handled by a non-specialist human professional who was not involved in any other validation stages. The latter used the system developing the schedules and transcribed the results presented by the system in a table exactly the same as the one filled in by the human specialists. This step was important so that future validators would not be able to distinguish the schedules set up by the schedule system from the schedules set up by the human specialists, thus avoiding potential biases. For the other validation steps, the system was treated as another specialist, receiving the number six.

In the third and final stage, all reviews and schedules carried out, both by human specialists and by the system, were evaluated and validated through consensus by five professionals with extensive clinical and research experience in the pharmacotherapy review process. These specialists are referred to in this work as "Validator Experts" (VEs). A blinding process was used, so that the VEs did not know which schedule had been set by a pharmacist or by the system, as they had not participated in the previous stages of the system development and registration.

For the data collection of the schedules' quality indicators a data collection instrument adapted from the Índice de Adequação de Medicação (IAM, Medication Adequacy Index) was used. This instrument was developed by Hanlon et al. ${ }^{14}$ based on a literature review on assessment measures or medication assessment scales. Subsequently, the IAM was validated by Samsa et al. ${ }^{15}$. The adaptation of this instrument was called Índice de Avaliação da Revisão da Farmacoterapia (IARF, Pharmacotherapy Review Assessment Index) and is presented in Table 2: 
Table 2

- Pharmacotherapy Review Assessment Index (IARF).

\begin{tabular}{|c|c|c|c|c|c|}
\hline \multirow[t]{2}{*}{1} & \multirow{2}{*}{$\begin{array}{l}\text { Are there any medications that are not } \\
\text { indicated for the patient? }\end{array}$} & 1 & 2 & 3 & 9 \\
\hline & & No & $\begin{array}{l}\text { Yes, but } \\
\text { acceptable }\end{array}$ & Yes & $\begin{array}{l}\text { I do } \\
\text { not } \\
\text { know }\end{array}$ \\
\hline \multirow[t]{2}{*}{2} & \multirow{2}{*}{$\begin{array}{l}\text { Are there any medication that could have } \\
\text { been replaced by a more effective one? }\end{array}$} & 1 & 2 & 3 & 9 \\
\hline & & No & $\begin{array}{l}\text { Yes, but } \\
\text { acceptable }\end{array}$ & Yes & $\begin{array}{l}\text { I do } \\
\text { not } \\
\text { know }\end{array}$ \\
\hline \multirow[t]{2}{*}{3} & \multirow{2}{*}{$\begin{array}{l}\text { Is any medication in the wrong dosage for } \\
\text { the patient? }\end{array}$} & 1 & 2 & 3 & 9 \\
\hline & & No & $\begin{array}{l}\text { Yes, but } \\
\text { acceptable }\end{array}$ & Yes & $\begin{array}{l}\text { I do } \\
\text { not } \\
\text { know }\end{array}$ \\
\hline \multirow[t]{2}{*}{4} & \multirow{2}{*}{$\begin{array}{l}\text { Are any medication specified with } \\
\text { incorrected or inadequate administration? }\end{array}$} & 1 & 2 & 3 & 9 \\
\hline & & No & $\begin{array}{l}\text { Yes, but } \\
\text { acceptable }\end{array}$ & Yes & $\begin{array}{l}\text { I do } \\
\text { not } \\
\text { know }\end{array}$ \\
\hline \multirow[t]{2}{*}{5} & \multirow{2}{*}{$\begin{array}{l}\text { According with patient's routine, is there any } \\
\text { medication in which the hours of use are } \\
\text { inadequate? }\end{array}$} & 1 & 2 & 3 & 9 \\
\hline & & No & $\begin{array}{l}\text { Yes, but } \\
\text { acceptable }\end{array}$ & Yes & $\begin{array}{l}\text { I do } \\
\text { not } \\
\text { know }\end{array}$ \\
\hline \multirow[t]{2}{*}{6} & \multirow{2}{*}{$\begin{array}{l}\text { Does any medication have drug interaction } \\
\text { that can cause harm for the patient? }\end{array}$} & 1 & 2 & 3 & 9 \\
\hline & & No & $\begin{array}{l}\text { Yes, but } \\
\text { acceptable }\end{array}$ & Yes & $\begin{array}{l}\text { I do } \\
\text { not } \\
\text { know }\end{array}$ \\
\hline \multirow[t]{2}{*}{7} & \multirow{2}{*}{$\begin{array}{l}\text { Are there any medication that should do not } \\
\text { be used due the special conditions or clinical } \\
\text { situations of the patient? }\end{array}$} & 1 & 2 & 3 & 9 \\
\hline & & No & $\begin{array}{l}\text { Yes, but } \\
\text { acceptable }\end{array}$ & Yes & $\begin{array}{l}\text { I do } \\
\text { not } \\
\text { know }\end{array}$ \\
\hline \multirow[t]{2}{*}{8} & \multirow{2}{*}{$\begin{array}{l}\text { Is there unnecessary duplication of } \\
\text { prescription? }\end{array}$} & 1 & 2 & 3 & 9 \\
\hline & & No & $\begin{array}{l}\text { Yes, but } \\
\text { acceptable }\end{array}$ & Yes & $\begin{array}{l}\text { I do } \\
\text { not } \\
\text { know }\end{array}$ \\
\hline \multirow[t]{2}{*}{9} & \multirow{2}{*}{$\begin{array}{l}\text { Are there any medications in which the } \\
\text { minimum time between doses is a risk for } \\
\text { the patient? }\end{array}$} & 1 & 2 & 3 & 9 \\
\hline & & No & $\begin{array}{l}\text { Yes, but } \\
\text { acceptable }\end{array}$ & Yes & $\begin{array}{l}\text { I do } \\
\text { not } \\
\text { know }\end{array}$ \\
\hline
\end{tabular}

Source: Adapted from Hanlon et al. (1992) ${ }^{14}$ 


\begin{tabular}{|llllll|}
\hline $\mathbf{1}$ & $\begin{array}{l}\text { Are there any medications that are not } \\
\text { indicated for the patient? }\end{array}$ & $\mathbf{1}$ & $\mathbf{2}$ & $\mathbf{3}$ & $\mathbf{9}$ \\
& No & $\begin{array}{l}\text { Yes, but } \\
\text { acceptable }\end{array}$ & Yes & $\begin{array}{l}\text { I do } \\
\text { not } \\
\text { know }\end{array}$ \\
\hline $10 \quad \begin{array}{l}\text { Overall, you consider this review of } \\
\text { pharmacotherapy }\end{array}$ & $\begin{array}{l}1 \\
\text { Adequate }\end{array}$ & 2 & 3 & 9 \\
Source: Adapted from Hanlon et al. $(1992)^{14}$ & & $\begin{array}{l}\text { Partially } \\
\text { adequate }\end{array}$ & Inadequate & $\begin{array}{l}\text { I do } \\
\text { not } \\
\text { know }\end{array}$ \\
\hline
\end{tabular}

The questions were prepared in such a way that the lowest score answer (1 - No) will always be optimal and the sum of the answers, for an optimal situation, should attain a maximum of 10 points.

The degree of agreement between the schedules assessments that were carried out by the pharmaceutical experts and by the system was measured using the Kappa index with a 95\% confidence interval.

This study was approved by the Research Ethics Committee of the University of Southern Santa Catarina (UNISUL) under CAAE number 20992713.60000.5369 and under Opinion number 461.125.

\section{Results And Discussion}

With the IARF of each hypothetical case, the aspects that cause the most errors in the Pharmacotherapy Review process were verified. Three aspects were selected to be analyzed: the identification of intentional errors, the adequate adjustment of medication usage schedule and the final classification of the VEs, which established whether the review and scheduling are considered adequate, partially adequate or inadequate. The results for each aspect evaluated are presented in Table 3: 
Table 3

IARF assessment results.

\begin{tabular}{|llllll|}
\hline Revisor & $\begin{array}{l}\text { Identification of } \\
\text { intentional erros }\end{array}$ & $\begin{array}{l}\text { Proper schedule } \\
\text { adjustment }\end{array}$ & \multicolumn{3}{l|}{ Final classification } \\
\cline { 4 - 6 } & $(\%)$ & $(\%)$ & $\begin{array}{l}\text { Adequate } \\
(\%)\end{array}$ & $\begin{array}{l}\text { Partially } \\
\text { Adequate } \\
(\%)\end{array}$ & $\begin{array}{l}\text { Inadequate } \\
\text { (\%) }\end{array}$ \\
\hline Specialist 1 & 20.0 & & 65.0 & 10.0 & 25.0 \\
\hline Specialist 2 & 40.0 & 40.0 & 73.0 & 7.0 & 20.0 \\
\hline Specialist 3 & 30.0 & 80.0 & 62.0 & 10.0 & 28.0 \\
\hline Specialist 4 & 50.0 & 60.0 & 69.0 & 9.0 & 22.0 \\
\hline Specialist 5 & 70.0 & 70.0 & 75.0 & 11.0 & 14.0 \\
\hline $\begin{array}{l}\text { Electronic } \\
\text { system }\end{array}$ & 80.0 & 80.0 & 88.0 & 6.0 & 6.0 \\
\hline
\end{tabular}

In these three aspects of evaluation, the system obtained a greater number of correct answers as compared to those of the pharmaceutical experts. The identification of intentional errors by the system was not well evaluated in the hypothetical case where a drug that is not indicated for the patient's clinical condition appears in the prescription. The reason is due to the fact that the system does not automatically remove the drug from the prescription it only warns and leaves the decision to the user. The VEs considered that an observation should be included in the schedule, informing if a drug is contraindicated, but decided not to proceed. The other case was the prescription of the drug "alendronate sodium": the VEs considered that the directions on the use of this drug should be more detailed when related to the schedule and include information based on the Ministry of Health clinical protocol ${ }^{16}$. For these two situations, adjustments in the registration of medications would resolve the negative assessment of the review by the system.

Regarding the schedules adjustment, those set up by the system were the only ones that were considered adequate in $100 \%$ of the reviews. Therefore, the selection of GA as the main system intelligence resource proved to be efficient in adjusting the medications use schedule. Optimization problems, in general, have a finite space of solutions and restrictions for solutions to be considered about adequate. In order to carry out the scheduling with the selection of the most adequate times for the medicine use, the finite space for solutions is constituted by the hours of the day and the medicines that need to be scheduled. The restrictions are the patient's routine impositions and the interactions between medications and between medications and food that sometimes end up causing the patient to abandon treatment ${ }^{17}$. In some cases, there are a lot of restrictions, which would prevent other algorithms from finding a solution. The GAs, even without finding an optimal solution, show the best solution found given the restrictions related to the patient's routines. 
Finally, in the last classification of the pharmacotherapy review, the reviews made by the system were those that obtained the best ratings, being considered adequate (88\%). The pharmaceutical expert who came closest to this rate obtained $75 \%$ of the reviews considered adequate.

In an attempt to establish agreement between the reviews carried out by the pharmaceutical experts and the reviews carried out by the system, the indices presented in Table 4 were obtained. The reviews carried out by the pharmaceutical experts were called $A 1, A 2, A 3, A 4$ and $A 5$ and the review performed by the system was called A6.

Table 4

Agreement rates between pharmaceutics experts and electronic system among pharmacotherapy review.

\begin{tabular}{|lll|}
\hline & Weighted Kappa & Cl 95\% \\
\hline A6-A1 & 0.3547 & $(0.1926-0.5168)$ \\
\hline A6-A2 & 0.3719 & $(0.1823-0.5615)$ \\
\hline A6 - A3 & 0.3458 & $(0.1907-0.501)$ \\
\hline A6 - A4 & 0.3971 & $(0.2241-0.5701)$ \\
\hline A6 - A5 & 0.4790 & $(0.2759-0.6822)$ \\
\hline Cl = Confidence Level & \\
\hline
\end{tabular}

The agreement rate obtained was considered reasonable $(0.21-0.40)$. The highest agreement occurred with the A5 schedule, and was considered moderate $(0.41-0.60)$. The initial hypothesis was that the system was capable of reproducing the reasoning of the pharmaceutical experts and setting the schedules with the same quality standard. However, the results obtained show that the system surpassed the schedule quality performed by human specialists, mainly in the identification of prescription errors and adequacy of schedules in connection with the patients' routine. The low levels of agreement are then interpreted as positive, since the revisions carried out by the system were better evaluated qualitatively.

The number of pharmaceutical experts who set the schedules to be compared with the schedules set by the system (5) and the number of simulated hypothetical cases (10) are not sufficient to establish a statistically significant sample, which was a limitation of this study. However, it was possible to verify that the system was able to set schedules with a standard of equal quality and even superior to those of the experts who participated in the investigation. This according to the evaluation carried out by the VEs.

Establishing the system's reliability index would be a feature that could be used to validate the system for reproducibility, that is, to validate multiple schedules of the same hypothetical case, performed by the system, at different times, and verify that all these schedules would be classified as "adequate". This analysis was not performed because the only way to assess whether the schedule is adequate or not, in 
the methodological parameters that were used, would be through the validation performed by the VEs in the consensus meetings, which would demand an excessive time for analysis thus making the process unfeasible.

It is noteworthy that the system only obtains good results if the registrations are carefully performed. The intelligent reasoning provided by GA will only work if the database has the correct relationships, including with regard to writing patterns and the qualities of observations. The cases in which the system did not obtain the expected result included situations in which the adjustment in the medication record would have cured the fault indicated by the EVs. In the pharmaceutical care settings where medications are dispensed, the main difficulties found for the pharmacotherapy review service to be fully carried out are the lack of quality information and the excessive time required to look for prescription potential inconsistencies and for suggesting a drug use strategy considering the patient's routine.

Failure to carry out the review of pharmacotherapy as recommended by the WHO has a direct impact on the RUM promotion, since the pharmacist, through a set of actions called pharmaceutical care (PC), which includes pharmacotherapy review, is an extremely important agent in promoting the RUM, interacting between the prescriber and the drug end user.

The fast search for information can be performed using an information system; however, in addition to having the information available, it is necessary to handle it, to establish the adjustment of doses and schedule consistent with the patient's routine; hence, this system can be used as a resource to support decisions, with the final decision always being the responsibility and the technical competence of human beings.

\section{Conclusion}

It can be concluded that with the methodology used, the investigation met the objectives and confirmed the initial hypothesis, since the system was able to produce results considered adequate by the VEs, being able to set quality schedules, as fast as the computerization processes allow, in addition to the security of producing results without interference of contextual factors to which human beings are susceptible.

The fact that the system was able to identify the highest rate of intentional errors (80\%), surpassing all human experts, proves that once the database (inference base) is correctly modeled and registered, it will never cease to identify the errors, and it is up to the human expert to make the clinical decisions, based on other information that is not part of the scope of the system.

\section{Abbreviations}

Al: Artificial Intelligence; $\mathrm{Cl}$ = Confidence Level; GA: Genetic Algorithms; IAM: Medication Adequacy Index; IARF: Pharmacotherapy Review Assessment Index; PC: Pharmaceutical care; RUM: Rational Use of Medicines; VEs: Validator Experts; WHO: World Health Organization; 


\section{Declarations}

\section{Ethical approval and consent to participate}

This study was approved by the Research Ethics Committee of the University of Southern Santa Catarina (UNISUL) under CAAE number 20992713.60000.5369 and under Opinion number 461.125

\section{Consent for publish}

Informed consent form applied to participants

\section{Availability of data and materials}

The data that support the findings of this study are available from, but restrictions apply to the availability of these data, which were used under license for the current study, and so are not publicly available. Data are however available from the authors upon reasonable request and with permission of: https://riuni.unisul.br/bitstream/handle/12345/4838/Tese\%20RIUNI.pdf?sequence=4\&isAllowed=y

\section{Competing interests}

The authors declare that they have no competing interests

Funding: Not applicable

\section{Authors contibuitions}

CMZ, DG e DJT designed the study, designed the computational framework, analyzed the data, and wrote the thesis.

FST, ASS, GMA, KSCM, SCT, wrote the first version of the manuscript, and critically revised the article.

All authors read and approved the final manuscript.

Acknowledgements: Not applicable

\section{References}

1. Chambers P. Rational use of medicines. Rev Rec 2011;169(9)226-7.

2. Ministério da Saúde. Secretaria de Ciência, Tecnologia e Insumos Estratégicos. Departamento de Assistência Farmacêutica e Insumos Estratégicos. Uso Racional de Medicamentos: temas relacionados. Interações de medicamentos. Volume 2016. Brasília, 2012. Disponível em: http://bvsms.saude.gov.br/bvs/publicacoes/uso_racional_medicamentos_temas_selecionados.pdf (acesso em 15/12/2020). 
3. Geurts MME, Talsma J, Brouwers JRBJ, Gier JJ. Medication review and reconciliation with cooperation between pharmacist and general practitioner and the benefit for the pacient: a systematic review. Br J Clin Phamacol 2012;74(1):16-33.

4. Rozenfeld S, Giordani F, Coelho S. Eventos adversos a medicamentos em hospital terciário: estudo piloto com rastreadores. Rev Saude Pública 2013;47(6):1102-11.

5. Zermansky AG, Petty DR, Raynor DK, Freemantle N, Vail A, Lowe CJ. Randomised controlled trial of clinical medication review by a pharmacist of elderly patients receiving repeat prescriptions in general practice. BMJ 2001;323(7325):1340-3.

6. Byron K, Bluvshtein V, Lucke L. Genetic algorithm optimization of transcutaneous energy transmission systems for implatable ventricular assist devices. Conf Proc IEEE Eng Med Biol Soc. 2013:659-62.

7. Linden R. Algoritmos Genéticos. Rio de Janeiro: Brasport, 2012.

8. Carvalho A, Eduardo MB. Sistemas de Informação em Saúde para Municípios. São Paulo: Faculdade de Saúde Pública da Universidade de São Paulo, 1998. 101p.

9. Hillestad R, Bigelow J, Bower A, Girosi F, Meili R, Scoville R, et al. Can eletronic medical records systems transform health care? Potential health benefits, saving, and costs. Health Aff (Millwood) 2005;24(5):1103-17.

10. Editorial Overview. The Role of Information Systems Research 2011;22(3):419-28.

11. Corrêa LCL, Beccaria LM, Amorin RC, Pacheco SS, Vacondio S, Fechio PB. Nursing data collection in a coronary unit: instrument validation. Arq ciênc saude 2008;15(2):59-64.

12. Alexandre NM, Coluci MZ. Content validity in the development and adaptation processes of measurement instruments. Ciênc Saude Colet 2011;16(7):3061-8.

13. Lima NDC, Silva VMD, Beltrão BA. Construction and validation of data collection instrumet content in a neonatal intensive care unit. Rev Rene 2009;10(3):97-106.

14. Hanlon JT, Schmader KE, Samsa GP, Weinberger M, Uttech KM, Lewis IK, et al. A method for assessing drug therapy appropriateness. J Clin Epidemiol 1992;45(10):1045-51.

15. Samsa GP, Hanlon JT, Schmader KE, Weinberger M, Clipp EC, Uttech KM, et al. A summated score for the medication appropriateness index: development and assessment of clinimetric properties including content validity. J Clin Epidemiol 1994;47(8):891-6.

16. Ministério da Saúde. Protocolo Clínico e Diretrizes Terapêuticas Osteoporose. Portaria Secretaria de Atenção à Saúde n 451, de 9 de junho de 2014. Disponível em: http://portalsaude.saude.gov.br/images/pdf/2014/ dezembro/15/Osteoporose.pdf.

17. Cesarino EJ et al. Fatores influentes na adesão ao tratamento anti-hipertensivo em pacientes hipertensos. Arq ciênc saúde. 2017;24(1):110-5. 